\title{
Scabbard trachea in medullary thyroid cancer
}

\author{
Pallvi Kaul (다, ${ }^{1}$ Rahul Kumar, ${ }^{1}$ Pranoy Paul, ${ }^{2}$ Pankaj Kumar Garg (ㄱ) ${ }^{1}$
}

${ }^{1}$ Surgical Oncology, All India Institute of Medical Sciences, Rishikesh, Uttarakhand, India ${ }^{2}$ Pathology, All India Institute of Medical Sciences, Rishikesh, Uttarakhand, India

\section{Correspondence to} Dr Pankaj Kumar Garg, Additional Professor and Head, Department of Surgical Oncology, All India Institute of Medical Sciences, Rishikesh, Uttarakhand, India; dr.pankajgarg@gmail.com

Accepted 11 April 2021

\section{DESCRIPTION}

A 65-year-old woman presented to us with a neck mass of 4-month duration and progressive dyspnoea for 1 month. Clinical examination revealed a $4 \times 3 \mathrm{~cm}$ firm mass involving the right lobe of the thyroid gland which moved with deglutition. The left lobe, however, was not palpable on clinical examination. Pemberton's sign was positive. A 70 degree endoscopy of the larynx revealed normal vocal cord mobility. She was clinically and biochemically euthyroid. A chest roentgenogram revealed a grade I retrosternal extension with a scabbard trachea (figure 1A). A contrastenhanced CT scan was done to assess the local extent of the mass including the inferior limit and tracheal invasion (figure 1B). Contrary to the clinical findings, the left lobe of the thyroid also showed a significant enlargement especially in its inferior part with a $7.5 \mathrm{~cm}$ craniocaudal extension, reaching up to the carina. The anterior mediastinal component measured $5.8 \times 4.3 \mathrm{~cm}$ (anteroposterior $\times$ transverse). The mass showed coarse calcification within it. Anteriorly, the mass was abutting the manubrium sterni with the displacement of the trachea and oesophagus towards the right side due to the predominant retrosternal component of the left lobe. The mass was closely abutting the great vessels without any luminal compromise. A true-cut biopsy from the mass was suggestive of medullary carcinoma thyroid. Immunohistochemistry showed intratumoral calcitonin positivity (figure 2). The case was discussed in the multidisciplinary tumour board and a plan to proceed with surgery was advised. The case, management options and the prognosis of the disease were discussed in detail with the patient and caregivers. However, the patient denied both the definitive surgery and tracheostomy to secure the airway and opted for hospice care.

The scabbard is a sheath for a sword, dagger or bayonet. The intrathoracic part of the trachea

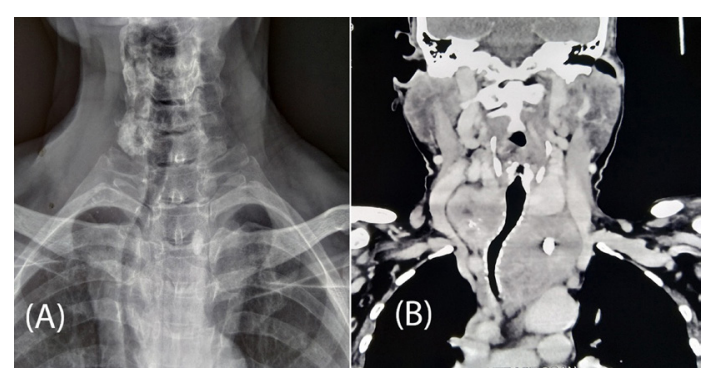

Figure 1 (A) Chest roentgenogram and (B) coronal section of the $\mathrm{CT}$ scan showing large retrosternal extension of the thyroid mass with coronal narrowing of the intrathoracic part of the trachea.

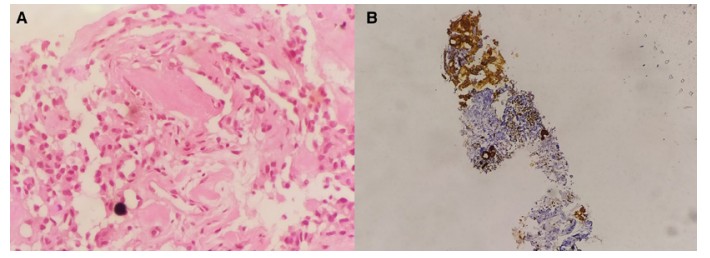

Figure 2 Photomicrographs showing (A) predominantly amyloid and one focus showing plasmacytoid and spindle-shaped tumour cells, $\times 40$ magnification, H\&E.

(B) Diffuse cytoplasmic staining with calcitonin, $\times 4$ magnification.

develops coronal narrowing and sagittal elongation, leading to decreased tracheal index and resemblance to a scabbard. Chronic obstructive pulmonary disease and retrosternal extension of thyroid mass are common conditions associated with this entity. ${ }^{1}$ The most common symptoms associated with such huge thyroid masses with retrosternal extension are those related to compression of the airway and oesophagus. ${ }^{2}$ Retrosternal thyroid masses can usually be surgically approached through a cervical incision. In a retrospective analysis of 115 patients with retrosternal goitre, Wang et al reported that mere three patients required an extracervical surgical approach. ${ }^{3}$ However, Monchik et al, based on their retrospective review of 976 patients undergoing thyroid surgery, suggested that a thoracic approach was necessary for thyroid masses with intrathoracic extension in which at least $50 \%$ of the mass was below the thoracic inlet. ${ }^{4}$ Diligent preoperative planning, based on the findings of CT of the neck and chest, is essential before resecting a large retrosternal goitre for optimal surgical outcomes.

\section{Learning points}

A positive Pemberton's sign with progressive symptoms in a patient with thyroid swelling mandates a CT scan to rule out any retrosternal extension.

- Scabbard trachea is usually seen in retrosternal goitres, with a female preponderance. Rapidly developing signs and symptoms should raise suspicion for malignancy.

- Scabbard trachea may be associated with tracheomalacia, especially in patients with long-standing goitre and chronic obstructive pulmonary disease. Hence, the anticipated possibility of the event and algorithm for management must be established in the preoperative period. 


\section{Twitter Pankaj Kumar Garg @DrPankajGarg}

Contributors PK: (1) Substantial contributions to the conception or design of the work, or the acquisition, analysis or interpretation of data; (2) drafting the work or revising it critically for important intellectual content; (4) agreement to be accountable for all aspects of the work in ensuring that questions related to the accuracy or integrity of any part of the work are appropriately investigated and resolved. PP: (1) Substantial contributions to the conception or design of the work, or the acquisition, analysis or interpretation of data; (2) drafting the work or revising it critically for important intellectual content; (4) agreement to be accountable for all aspects of the work in ensuring that questions related to the accuracy or integrity of any part of the work are appropriately investigated and resolved. RH: (1) Substantial contributions to the conception or design of the work, or the acquisition, analysis or interpretation of data; (2) drafting the work or revising it critically for important intellectual content; (4) agreement to be accountable for all aspects of the work in ensuring that questions related to the accuracy or integrity of any part of the work are appropriately investigated and resolved. PKG: (1) Substantial contributions to the conception or design of the work, or the acquisition, analysis or interpretation of data; (2) drafting the work or revising it critically for important intellectual content; (3) final approval of the version published; (4) agreement to be accountable for all aspects of the work in ensuring that questions related to the accuracy or integrity of any part of the work are appropriately investigated and resolved.
Funding The authors have not declared a specific grant for this research from any funding agency in the public, commercial or not-for-profit sectors.

Competing interests None declared.

Patient consent for publication Consent obtained from next of kin

Provenance and peer review Not commissioned; externally peer reviewed.

\section{ORCID iDs}

Pallvi Kaul http://orcid.org/0000-0003-4003-6430

Pankaj Kumar Garg http://orcid.org/0000-0001-9760-5484

\section{REFERENCES}

1 Ray A, Sindhu D. Scabbard trachea. Egyptian Journal of Bronchology 2019;13:441-2.

2 Bizakis J, Karatzanis A, Hajiioannou J, et al. Diagnosis and management of substernal goiter at the University of Crete. Surg Today 2008;38:99-103.

3 Wang X, Zhou Y, Li C, et al. Surgery for retrosternal goiter: cervical approach. Gland Surg 2020;9:392-400

4 Monchik JM, Materazzi G. The necessity for a thoracic approach in thyroid surgery. Arch Surg 2000;135:467-71.

Copyright 2021 BMJ Publishing Group. All rights reserved. For permission to reuse any of this content visit

https://www.bmj.com/company/products-services/rights-and-licensing/permissions/

BMJ Case Report Fellows may re-use this article for personal use and teaching without any further permission.

Become a Fellow of BMJ Case Reports today and you can:

- Submit as many cases as you like

- Enjoy fast sympathetic peer review and rapid publication of accepted articles

- Access all the published articles

Re-use any of the published material for personal use and teaching without further permission

\section{Customer Service}

If you have any further queries about your subscription, please contact our customer services team on +44 (0) 2071111105 or via email at support@bmj.com.

Visit casereports.bmj.com for more articles like this and to become a Fellow 